Revista de Estudios Histórico-Jurídicos

[Sección historia del derecho de la Antigüedad salvo el romano]

XLII (Valparaíso, Chile, 2020)

[pp. 39-65]

\title{
REFUGIADOS POLÍTICOS, CAUTIVOS, ESCLAVOS Y OTROS EMIGRADOS EN EL DERECHO INTERNACIONAL DEL ANTIGUO Oriente Medio (II Milenio A.C.)
}

[Political refugees, captives slaves and other migrants in the international law of the Ancient Middle East (II millennium b. C.)]

\author{
Víctor Manuel SÁNCHEZ-SÁNCHEZ* \\ Universitat Oberta de Catalunya, España
}

\section{RESUMEN}

Los tratados internacionales del II Milenio a. C. en el Antiguo Oriente Medio (AOM) muestran la importancia que adquirió por entonces la regulación de flujos migratorios. Los fundamentos económicos y políticos de estas normas facilitan trazar análisis críticos comparados con el derecho internacional actual relativo a los mismos fenómenos. La pérdida de rentabilidad social de los seres humanos como consecuencia de los cambios demográficos explicaría la diferencia copernicana en los modelos normativos pasados y presentes. La variedad de cláusulas de extradición existentes en los tratados evidencia los problemas a los que daba lugar la convergencia de los criterios personal y territorial para reclamar el ejercicio de la jurisdicción en el primer momento de cristalización de grandes estados territoriales. La vulneración de las obligaciones de captura y extradición fijadas era alegada como una causa justa para el recurso a la guerra. Sólo la recuperación del valor económico humano permitirá el cambio de la regulación actual de los flujos migratorios.

\section{AbSTRACT}

The international treaties of the second millennium b. C. in the Ancient Middle East (AME) show the importance that the regulation of migratory flows acquired at that time. The economic and political foundations of these norms make it easy to draw critical analyzes compared to current international law regarding the same phenomena. The loss of social profitability of human beings as a consequence of demographic changes would explain the Copernican difference in past and present normative models. The variety of extradition clauses existing in the treaties shows the problems caused by the convergence of personal and territorial criteria to demand the exercise of jurisdiction in the first moment of crystallization of large territorial states. The violation of the capture and extradition obligations established was alleged as a just cause for the recourse to war. Only the recovery of human economic value will allow the change in the current regulation of migratory flows.

* Doctor por la Universidad de Barcelona. Profesor Agregado de Derecho Internacional Público. Director Máster Universitario en Derechos Humanos, Democracia y Globalización UOC; Director del Master in International Affairs and Diplomacy, Uoc-UnITAR. 


\section{Palabras clave}

Historia del derecho internacional refugiados - cautivos de guerra - ius ad bellum - ius in bello-derecho internacional antiguo - ius publicum europeum - derecho de tratados - inmigración - prisioneros de guerra.

\section{Key Words}

History of international law - refugees - war captives - ius ad bellum - ius in bello - ancient international law - ius publicum europeum - law of the treaties - immigration - war prisoners.

RECIBIDO el 30 de octubre de 2019 y ACEPTADO el 23 de abril de 2020

\section{Emigrantes, tratados y correspondencia del Antiguo Oriente Medio}

Los primeros estados territoriales en los que claramente la jurisdicción de un rey con poderes soberanos se ejercía sobre una base territorial extensa, superadora de las ciudades-estado comerciales, se configuran en el II milenio a. C. del AOM. Los tratados internacionales supervivientes contienen abundantes y precisas cláusulas que regulan todos los elementos constitutivos del Estado: delimitación fronteriza ${ }^{1}$, reconocimiento de gobiernos ${ }^{2}$, naturaleza y consecuencias de la soberanía territorial ${ }^{3}$, y control de los flujos de población que es el objeto específico de este artículo. Con estas normas se creaban obligaciones y derechos relativos al uso de acuíferos, reglas de paso para el comercio internacional, normas de usos sobre templos de culto en zonas limítrofes, o de control sobre tribus nómadas que tradicionalmente se movían por los territorios demarcados.

A través de los tratados internacionales ${ }^{4}$, cartas diplomáticas ${ }^{5}$ y otros textos

${ }^{1}$ Contienen cláusulas de delimitación fronteriza el Tratado entre Tudhaliya II de Hatti y Šunašsura de Kizzuwatna (CTH41), \$\$ 62-64; Tratado entre Šuppiluliuma I de Hatti y Šattiwaza de Mittanni (CTH 51) \$10; Tratado entre Muršili II de Hatti y Kupanta-Kurunta de MiraKuwaliya (CTH 68), \$9; Tratado entre Hattušili III de Hatti y Ulmi-Teššup de Tarhuntašsa, $\$ 3$; Tratado entre Tudhaliya IV de Hatti y Kurunta de Tarhuntašsa (CTH 106), \$\$ 3-11. Respectivamente en Beckman, Gary M., Hittite diplomatic texts (Atlanta, Scholars Press, 1996), pp. 21, 41, 71, 104-5, 109-111. Todas las traducciones al español de los tratados son propias realizadas a partir de la versión en inglés de Beckman, salvo que se indique otra cosa con respecto a a la autoría de la traducción o el texto tomado como referencia para realizar la misma.

${ }^{2} \mathrm{~A}$ veces explícito, otras no, en todas las cláusulas de sucesión, lealtad mutua o asistencia mutua frente a la rebelión, otro de los ejes de los tratados. Véase, por ejemplo, $\$ 11$ Tratado entre Tudhaliya II de Hatti y Šunǎšura de Kizzuwatna; $\$ \$ 5$ y 6, cit. supra; y Tratado entre Šuppiluliuma I de Hatti y Huqqana de Hayasa (CTH 42); pp. 15-6, p. 24.

${ }^{3} \$ 10$, Tratado entre Muršili II de Hatti y Kupanta-Kurunta de Mira-Kuwaliya; $₫ 2$, cit. sup.; Tratado entre Tudhaliya IV de Hatti y Šausgamuwa de Amurru (CTH, 105), \$26; Tratado entre Tudhaliya IV de Hatti y Kurunta de Tarhuntašsa (Bo 86/299), BECKMAN, Gary M., cit. (n. 1), pp. 71, 104, 116.

${ }^{4}$ Una veintena aproximadamente siguiendo los textos de BECKMAN, Gary M., cit. (n. 1), pp. 11-118. Todos ellos se citarán con arreglo a la versión inglesa de este autor, y se ofrece la indexación CTH, esto es, la ofrecida por LAROCHE, Emmanuel, Catalogue des textes hittites (Paris, Klincksieck, 1971).

${ }^{5}$ Para el centenar de cartas diplomáticas de los yacimientos hititas, Liverani, Mario, La lettere di el-Amarna (Paideia, Brescia, 1998-1999), 2 vols.; HOFFnER (JR.), Harry A., Letters form the Hittite Kingdom (Atlanta, Society of Biblical Literature, 2009); Weeden, Mark, State Correspondence in the Hittite World, en RADNER, Karen (ed.), State Correspondence in the Ancient 
procedentes sobre todo del antiguo mundo Hitita (circa 1500-1200 a. C.) ${ }^{6}-$ también de otros reinos circundantes ${ }^{7}$ - ha sobrevivido una información muy significativa que evidencia la existencia de continuos flujos de población a través de aquellas fronteras. Explicitan todos estos documentos la voluntad de fijar un régimen internacional que los regulara, constituido a través de racimos de tratados bilaterales ${ }^{8}$. Los términos empleados en acadio o hitita para referirse a personas que se desplazan de un Estado a otro son muy variados.

En la correspondencia encontramos con frecuencia el término hitita pitteyant. Simplemente denota a alguien que parte o marcha de la tierra en la que residía anteriormente. La palabra no permite distinguir si se trata de un esclavo que huye de su amo a otro territorio o de un fugitivo que huye por razones políticas? Esta Carta del Rey hitita a Kaššü $\bar{u}^{10}$, el "Jefe del Ejército de Inspectores" provincia hitita con competencia de vigilancia de los pasos fronterizos, ilustra el modo genérico de uso del término:

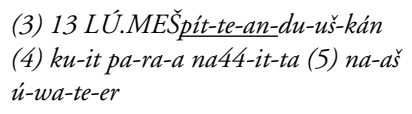

(3-5) Respecto al hecho de que (me) enviaste 13 los fugitivos (capturados): Me los han traido aqui.

Además, en los escritos en acadio también se utiliza con frecuencia la palabra hapirū para hacer también referencia a personas aparentemente venidas de otras tierras. A menudo se ofrecían como mercenarios a los ejércitos ${ }^{12}$. Algunos autores

World. From New Kingdom Egypt to the Roman Empire (Oxford - New York, Oxford University Press, 2014), p. 32. Todos ellos beben de Hagenbuchner, Albertine, Die Korrespondenz der Hethiter Albertine (Heidelberg, C. Winter, 1989), 2 vols. Además Hoffner (Jr.) se nutre de las posteriores cartas de Alp, Sedat, Hethitische Briefe aus Maşat-Höyük (Ankara, Turk Tarih Kurumu Basemevi, 1991).

${ }^{6}$ Sobre la historia política del reino, BRYCE, Trevor, The Kingdom of the Hittites (Oxford, Oxford University Press, 2005); Colurns, Billie Jean, The Hittites and their World (Atlanta, Society of Biblical Literature, 2007), pp. 37-90; KLENGEL, Horst, History of the Hittites, en GENZ Herman; Mielke, Dirk Paul (eds.), Insigths into Hittite History and Archaeology (Leuven-ParisWalpole MA, Peeters, 2011), pp. 31-46; Bernabé, Alberto; Álvarez-Pedrosa, Juan Antonio, (eds.), Historia y leyes de los hititas. Textos del Imperio Antiguo. El Código (Madrid, Akal, 2000), I, pp. 23-32.

${ }^{7}$ Otra parte de la correspondencia procede de Amarna. Es otro archivo oficial. 44 de las Cartas de Amarna contienen correspondencia diplomática de Egipto con otros reinos. Moran, William. L., The Amarna Letters (Baltimore - Londres, Johns Hopkins University Press, 1992); y Mynarova, Jana, Language of Amarna - Language of Diplomacy: Perspectives on the Amarna Letters (Praga, Czech Institute of Egyptology, 2007).

${ }^{8} \mathrm{~A}$ efectos de este texto el adjetivo b i l a t e r a 1 no implica igualdad de poder o de obligaciones entre las partes. Hace referencia únicamente a la existencia de dos partes obligadas. Vide infra la cuestión de la reciprocidad/no reciprocidad de las obligaciones asumidas, que permite la distinción entre tratados bilaterales entre iguales y tratados bilaterales desiguales o de vasallaje.

${ }^{9}$ Hoffner (Jr.), Harry A., cit. (n. 5), p. 111.

${ }^{10}$ Ibíd., p. 110.

${ }^{11}$ Ibíd., p. 95.

${ }^{12}$ Ibíd., p. 159. 
piensan que serían los h e b r e o ${ }^{13}$, personas pertenecientes a un conjunto de tribus seminómadas belicosas que dieron origen al pueblo de Israel, aunque esta interpretación es cuestionable en la identificación de los mismos como un grupo étnico por entonces ${ }^{14}$. Son numerosas las cartas en las que aparecen referenciados como grupos portadores de violencia a las tierras del Faraón ${ }^{15}$. En fin, el participio munnabtu es utilizado sistemáticamente en los tratados hititas para hacer referencia genérica a los $\mathrm{fugad}$ os o huid os igualmente sin distinguir la causa que motiva su partida ${ }^{16}$.

Aunque en los textos no siempre resulte claro el alcance de las normas, el conjunto de la información que nos proporciona la suma de tratados, correspondencia diplomática y otros documentos recuperados esbozan un cuadro revelador de la problemática subyacentes a estos movimientos de personas en aquella época y de las consecuencias jurídico-políticas asociadas a las abundantes cláusulas de devolución fijadas en los tratados bilaterales. El alto valor socio-económico de la población y el desvalor correspondiente a su pérdida acabó configurando u n p a tró n d e obligaciones de captura y extradición consideradas como una parte fundamental del derecho internacional del Bronce Tardío.

\section{RECIPROCIDAD O ASIMETRÍA EN LAS OBLIGACIONES DE EXTRADICIÓN}

Una primera forma de clasificación de las cláusulas de extradición es la que atiende a la reciprocidad o no del deber de extradición. Permite trazar conclusiones sobre la estructura de poder internacional en aquella área geográfica. Son escasos los convenios en las que las disposiciones relativas a la devolución o extradición son simétricas. Sólo cuatro de los veinte. La simetría de obligaciones de captura y extradición muestra una relación de igualdad o casi igualdad entre los firmantes. Los tratados sin reciprocidad evidencian una relación de subordinación con respecto a Hatti, una de las grandes potencias en el Bronce Tardío entre el 1500 y el 1200 a. C. Algunos tratados, por su carácter fragmentario, no permiten saber si las obligaciones de extradición eran de carácter recíproco ${ }^{17}$.

\footnotetext{
${ }^{13}$ Moran, William. L., cit. (n. 7), pp. 392-393.

${ }^{14}$ Killebrew, Ann E., Hybridity, Hapiru, and the Archaeology of Ethnicity in Second Millennium BCE Western Asia, en MCINERNEY, Jeremy (ed.), A Companion to Ethnicity in the Ancient Mediterranean (Chichester - West Sussex, Wiley Blackwell, 2014), pp. 142-157.

${ }^{15}$ Moran, William. L., cit. (n. 7), documentos EA 67, EA 68, EA 71, EA 73, EA 74, EA 75, EA 77, EA 79, EA 80, EA 82, EA 83, EA 85, EA 87, EA 88, EA 90, EA 91, EA 94, EA 104, EA 108, EA 112, EA 113, EA 117, EA 118, EA 121, EA 129, EA 130, EA 132, EA 146, EA 148, EA 179, EA 185, EA 186, EA 189, EA 195, EA 197, EA 207, EA 215, EA 254, EA 271, EA 272, EA 273, EA 274, EA 286, EA 287, EA 288, EA 289, EA 290, EA 298, EA 299, EA 305, EA 307, EA 313, y EA 366.

${ }^{16} \$ 1$ lin. 1-5 Tratado entre un Rey de Hatti y Paddatišu de Kizzuwatna de la transcripción del acadio Hethitilogie Portal Mainz, http://www.hethport.uni-wuerzburg.de/HPM/index.html.

${ }^{17}$ Tratado entre Niqmepa de Alalakh y Ir-Tešsup de Tunip (1425 a. C.) Texto en http:// etana.org/etact/search?subject=\%22Treaties $\% 22$ (vis. 21 octubre 2019).
} 


\section{Reciprocidad}

El Tratado entre Idrimi de Alalakh y Pilliya de Kizzuwadna contiene una cláusula con plena correspondencia mutua de obligaciones de extradición entre los dos soberanos. Es el objeto exclusivo del tratado. Se trata de dos reinos que son a su vez vasallos del Gran Rey de Hatti. Entre ellos las obligaciones de captura y extradición de huidos son plenamente recíprocas. Señala su igualdad formal plena. No se detalla la subclase de huidos a los que se aplicaba. Las partes quedan sujetas a mutuas obligaciones de captura y extradición que parecen extenderse a las personas privadas ${ }^{18}$. El tratado dispone además un mecanismo de cooperación interestatal fronteriza. Autorizaba a los s e ñ or e s de los fugitivos a entrar en el territorio del otro Estado y capturar a sus huidos. En este caso quedaban exonerados de pagar recompensa alguna: " $Y$ si un fugitivo perteneciente a Pilliya entra en el territorio de Idrimi, y nadie lo captura, excepto su señor, entonces él [el señor del fugitivo] no deberá pagar ningún rescate".

Contienen disposiciones de extradición de naturaleza recíproca otros tres tratados en los que es parte el Reino Hitita ${ }^{19}$. Sólo en el Tratado de Qadesh celebrado entre Hatti y Egipto la reciprocidad de obligaciones se extiende a todo el régimen de derechos y obligaciones. Esto evidencia la posición jerárquicamente igual de ambos grandes reinos. En los otros dos tratados, otras disposiciones no son recíprocas, así que serían indiciarios de la sumisión de la otra parte con respecto a Hatti.

\section{Sin reciprocidad}

Son más numerosos los tratados sin reciprocidad exacta de obligaciones, siempre en beneficio de Hatti. Esto coloca a los otros contratatantes -vasallos o protegidos- en una situación de subordinación ${ }^{20}$ en un aspecto esencial de su política: el control de flujos migratorios. La ausencia de correspondencia en los deberes puede ser de dos tipos: i) el reino de Hatti dispone de derechos de

18 "Cuando Pilliya e Idrimi hicieron un juramento ante los dioses, establecieron este pacto que les obligaba a ambos: De ahora en adelante, se devolverán siempre a los fugitivos entre si [...] $Y$ cualquiera que capture a un fugitivo, lo enviará de vuelta a su señor", en http://etana.org/etact/ search? subject $=\% 22$ Treaties $\% 22$ (vis. 21 octubre 2019). Muestra un tratado entre reyes iguales entre sí. Sobre Idrimi, Galvin, Garrett, Egypt as a Place for Refuge (Tubingen, Mohr Siebeck, 2011), pp. 23-27.

${ }^{19}$ Tratado entre un Rey de Hatti y Paddatišu de Kizzuwatna, $\$ \$ 1-2$ y $\$ \$ 5-6$, cit. supr.; Tratado entre Tudhaliya II de Hatti y Šunǎšura de Kizzuwatna, $\$ \$ 13-17$ texto acadio y $\$ \$ 2-3$ y $\$ \$ 5-$ 10 texto hitita, cit. supr.; Tratado entre Hattušili III de Hatti y Ramsés II de Egipto (CTH 91), $\$ \$ 12-19$. Respectivamente, en BECKMAN, Gary M., cit. (n. 1), pp. 12-13; 14-15; 21-22; 90-95.

${ }^{20} \mathrm{El}$ Tratado entre Tudhaliya IV de Hatti y Šaǔgamuwa de Amurru contiene una cláusula en la que el Rey hitita ordena al príncipe vasallo a tratar a sus amigos como amigos y a sus enemigos como enemigos. Nombra los reyes con el mismo rango que el Rey de Hatti por entonces. Cita a los de Egipto, Babilonia, Asiria y Ahhiyawa. Beckman, Gary M., cit. (n. 1), \$11 p. 101. Sobre las diferencias en las formas de subordinación de los reinos, Altman, Amnon, Rethinking the Hittite System of Subordinate Countries from the Legal Point of View, 123 JAOS (4, 2003), pp. 741-756; Beckman, Gary M., International Law in the Second Millenium: Late Bronze Age, en Westbrook, Raymond (ed.), A History of Ancient Near Eastern Law (Leiden - Boston, Brill, 2003), I, pp. 755-759. 
extradición de sus fugitivos que no asume con respecto a los de la otra parte; ii) o bien, su obligación de extradición no es simétrica, por establecer condiciones o modos de ejecución diferentes a los de la contraparte.

Una muestra de acuerdo de extradición sin reciprocidad es el Tratado entre Šuppiluliuma I de Hatti y Šattiwaza de Mittanni. El texto refleja la idea de que la capital Hatti se había convertido en una C i u d a d r e f u g i o para huidos y que desde su entrada en territorio del Gran Rey de Hatti pasaban a ser súbditos suyos $^{21}$. Tampoco hay reciprocidad alguna en el Tratado entre Šuppiluliuma I de Hatti y Huqqana de Hayasa ${ }^{22}$. En otros casos, mientras que la obligación de la otra parte es absoluta, la propia de Hatti es discrecional: puede o no conceder la devolución recibida la solicitud. En el Tratado entre Šuppiluliuma I de Hatti y Aziru de Amurru ${ }^{23}$, cuando se trata de la extradición de súbditos de Hatti huidos la obligación de Aziru es automática y absoluta. En cambio cuando se trata de expatriados del reino de Amurru, se debe solicitar la devolución y el rey Hitita decidirá discrecionalmente si procede ${ }^{24}$. Existen otros supuestos en los que la obligación de devolución de Hatti no es tan discrecional. El soberano de Hatti debía devolver al fugado cuando se lo solicitara la otra parte si se trataba de artesanos cualificados que abandonaban su país de origen con el fin de evitar el cumplimiento de alguna obligación profesional. Se estipula así en el Tratado entre Muršili II de Hatti y Targasnalli de Hapalla (circa 1300 a. C. $)^{25}$

\section{Política DEMOGRÁficA NATALISTA Y POLÍTICA MigRATORIA}

El Tratado entre Idrimi y Piliya, y los tratados con cláusulas de extradición no recíproca demuestran la existencia de políticas públicas demográficas y migratorias desde los orígenes más remotos del Estado territorial. Ambas están orientadas al mismo fin: mantener o incrementar la población dentro del Estado. El Tratado entre Idrimi y Piliya, además de las cláusulas de extradición sinalagmáticas, fijaba

21 "\$9. Si un fugitivo huye de Hatti en dirección a la tierra de Mitanni, los mitanos lo capturarán y lo devolverán. Si un fugitivo de la tierra de Mittani huye en dirección a Hatti, el Rey de Hatti no lo capturará ni lo devolverá. [...] La casa que el Príncipe Šattiwaza tiene en Hatti se hará cargo del fugitivo [...] pertenecerá a Hatti”. BECKMAN, Gary M., Hittite diplomatic texts, cit. (n. 1), p. 41 ( $C T H 49)$.

${ }^{22}$ Ibíd., $\$ \$ 15-18$, p. 26.

${ }^{23}$ Ibíd., pp. 35-36. "\$12. Si un hitita llega como fugitivo desde Hatti y se dirigie a tí, Aziru, captúrale y envialo al Rey de Hatti. Pero si no lo envias, entonces habrás roto el juramento".

${ }^{24}$ Ibíd., "\$13. Si un fugitivo huye de la tierra de Amurru y llega a Hatti, el Rey de Hatti no lo capturará ni lo devolverá (...) \$14. Y si tú, Aziru, quieres algo, pídeselo al Rey de Hatti, y toma lo que el Rey de Hatti te ofrezca. No debes tomar lo que el Rey de Hatti no te haya ofrecido".

${ }^{25}$ Ibíd., p. 66. "\$6. Si un cautivo civil bajo una obligación de servicio o un hombre libre llega procedente de la tierra de Hapalla bajo una obligación de servicio (?) o un hombre libre procedente de Hapalla llega a Hatti como fugitivo, no te lo devolveré. No está permitido devolver a un fugitivo desde Hatti. Pero si es agricultor, tejedor, carpintero o peletero, o cualquier otro tipo de artesano, que no haya entregado el trabajo asignado, y se fuga a Hatti, lo arrestaré y te lo devolverê" (CTH 67). También en Tratado entre Muwatalli II de Hatti y Alaksandu de Wiluša (CTH 76), ibíd., $\$ 15$ p. 86. 
recompensas por las devoluciones. Las mujeres tenían el doble de valor que los hombres ${ }^{26}$.

Esta disposición probaría la existencia de una p o lít i c a d e m og ráfica $\mathrm{n}$ a $\mathrm{t}$ a $\mathrm{l}$ i s $\mathrm{t}$ a en aquella época. Los soberanos eran conscientes de la necesidad de mantener la natalidad elevada como factor determinante para el mantenimiento de su economía y de este modo, de su poder e influencia política ${ }^{27}$. En esta primera etapa demográfica de la Humanidad los niveles altos de fecundidad debían compensar la alta mortalidad -ordinaria o catastrófica- e incluso permitir aspirar a su crecimiento. Por eso la mujer disponía de un valor superior al del hombre. Por su parte, la generalización de la regla de no reciprocidad de las extradiciones en los tratados bilaterales hititas deja constancia de su impulso imperial de una política migratoria expansiva plenamente coherente con su propia política demográfica natalista.

La ausencia general de reciprocidad en los tratados que celebraba el Gran Reino de Hatti con estados menores, además de ser una prueba manifiesta de su poder superior, demuestraría la articulación sistemática mediante pactos de una política migratoria que facilitara consolidar o incrementar aquel vector básico de su poderío. La política es imperial porque sólo podía basarse en la existencia de un poder fáctico superior que le permitera p e r s u a d i $\mathrm{r}$ a estados menos fuertes para que aceptaran una política migratoria que les perjudicaba a corto y medio plazo. En las fases de emergencia, consolidación y expansión de su gran Estado territorial, en competencia con otros grandes Estados del AOM -Egipto, Asiria, Babilonia-, Hatti debió estar siempre necesitada de crecimientos poblacionales positivos. En los albores de la civilización el régimen demográfico era el típico de las sociedades de base económica agrícola y guerrera: las tasas de natalidad y de mortalidad eran muy altas, el crecimiento de la población muy lento ${ }^{28}$ y con grandes riesgos de ser negativo por la materialización de fenómenos catastróficos (epidemias, sequías) difícilmente combatibles preventiva o reactivamente con los conocimientos técnicos y científicos de la época. La política migratoria impulsada sistemáticamente por Hatti facilitaba conservar y ampliar su población a través de las obligaciones de extradición de sus emigrantes exigidas sin reciprocidad a los otros contratantes. La posibilidad de saldo poblacional positivo crecía con el derecho a retener a los que inmigrantes que entraran en su territorio procedentes de estados subordinados.

Los pequeños estados no debían ser ajenos a las consecuencias negativas de esta política migratoria para su propio futuro. El Tratado entre Idrimi y Piliya, dos

\footnotetext{
26 "Si es un hombre, él (el señor del fugitivo) deberá pagar 500 shéquels de cobre como rescate, y si es una mujer se pagarán 1.000 shéquels de cobre”. Supra (n. 18).

${ }^{27}$ Véase también los $\$ \$ 5$ y 6, Tratado entre un Rey de Hatti y Paddatissu de Kizzuwatna (CTH 26), Beckman, Gary M., Hittite diplomatic texts, cit. (n. 1), pp. 1-13.

${ }^{28}$ Aplicando las ratios de crecimiento para aquella época dadas por BACCI, en el II milenio a. C. la población mundial se situaría entre veintisiete y cincuenta millones de personas. LIVI BACCI, Massimo, Storia minima della popolazione del mondo (Bologna, Società editrice il Mulino, 1998), pp. 41-44. Sobre las fases de transición demográfica véase el artículo clásico de KINGSLEY, Davis, The World Demographic Transition, en Annals of the American Academy of Political and Social Science, 237 (Philadelphia, 1945), pp. 1-11.
} 
estados menores pero iguales entre sí, ofrece una alta recompensa por la devolución de las mujeres y crea obligaciones sinalagmáticas de devolución de inmigrantes. Así que debieron aceptar como un mal menor este modo de regulación asimétrico de los flujos de personas. Como se verá, la desigualdad de poder hacía que rechazar las obligaciones de extradición no fuera sinónimo de mantener el control sobre su territorio: la guerra, otro fenómeno demográficamente catastrófico, podía hacer que el rechazo a la extradición fuera más ineficiente poblacionalmente a corto plazo.

\section{Tipología de PERSONAS A EXTRADitAR}

Otro modo de comprender el alcance de estas cláusulas de extradición de fugados y todo lo que nos explican de aquella época es atender a la causa política, civil o económica de estos movimientos ${ }^{29}$.

\section{Refugiados políticos}

Múltiples documentos indican que el Imperio Hitita estuvo continuamente sometido a rebeliones ${ }^{30}$. Los tratados de alianza y vasallaje hitita contienen una huella normativa muy profunda de esta realidad. Dentro de la sección esencial de disposiciones de alianza defensiva se incorporan con frecuencia obligaciones de asistencia militar mutua frente a actos de rebelión o sedición. ${ }^{31}$

Dicha inestabilidad política interna generaba refugiados que huían del castigo cuando la victoria caía del otro lado. ¿Qué hacer con ellos? Los tratados identifican con precisión la "creación de una obligación generalizada de devolución de los que buscan asilo por actos de rebelión contra el otro contratante" 32 como parte integrante de la alianza defensiva. Los soberanos aliados protegían celosamente sus tronos y mecanismos sucesorios frente a la traición. De modo complementario afloraban otras obligaciones de informar, no prestar apoyo o no fomentar la organización de fuerzas armadas con fines subversivos que tengan por finalidad hacer incursiones en el territorio de la otra parte. Las relaciones de buena vecindad, por ello, requerían una estricta alianza con el Gran Rey de Hatti que se extendía más allá de las típicas cláusulas de defensa mutua frente a la agresión exterior. La asistencia militar contra las rebeliones internas o sediciones, y la persecución

${ }^{29}$ Otras formas de clasificación en Westbrook, Raymond, Personal Exile in the Ancient Near East, en Journal of the American Oriental Society, 128, 2 (2008), p. 319; SNELL, Daniel C., Flight and Freedom in the Ancient Near East (Leiden - Boston, Brill, 2001), pp. 93-94.

${ }^{30}$ BRYCE, Trevor, cit. (n. 6), pp. 74-76; 86-92; 96-120; 121-122; 143; 199-201; 212-216; $246-265$.

31 "\$6 Y si otro enemigo se subleva contra el Rey de Hatti, y ataca Hatti, o si alguien encabeza una rebelión contra el Rey de Hatti, y tú, Aziru, oyes hablar de ello, y no acudes incondicionalmente en ayuda de Mi Majestad con infantería y carros de combate, habrás roto el juramento", Tratado entre Š uppiluliuma I de Hatti y Aziru de Amurru, Beckman, Gary M., Hittite diplomatic texts, cit. (n. 1), p. 34.

${ }^{32}$ En contra SNELL, para quien hasta el primer milenio antes de Cristo "it does not seem likely that until deportations in the first millenium BCE there were very many politically motivated refugees". SNELL, Daniel C., cit. (n. 29), p. 88. 
internacional de los rebeldes, formaban parte también de los contenidos básicos de los tratados de aquella época.

La obligación de capturar y extraditar se refiere explícitamente "a personas que han planeado o ejecutado un acto de desobediencia contra el soberano". Es el caso del Tratado entre un Rey de Hatti y Paddatišu de Kizzuwadna: "\$1. Si un súbdito del Gran Rey urde un complot contra su señor y luego huye a la tierra de Kizzuwadna, y el Gran Rey envía a alguien a buscar al fugitivo, diciendo: "Se ha rebelado contra mi. ;Quiero que me lo devuelvan?"33. Contienen estipulaciones similares otros seis tratados ${ }^{34}$. De entre ellos resulta muy explícito el $\$ 7$ del Tratado entre Muršili II y Targasnalli de Hapalla: "Pero si alguien busca matarte, a Targasnalli, o a tu hijo, pero luego escapa y llega a Hatti, ya que él es tu enemigo, también es el enemigo de Mi Majestad. Lo arrestaré y te lo devolverê".

En el Tratado entre Tudhaliya II de Hatti y Šunǎšura de Kizzuwadna ${ }^{35}$ la norma es más compleja: se establece una obligación alternativa de e x $\mathrm{t} r \mathrm{r}$ d i t a r o c a s t ig a r similar a la regla formulada al respecto por Grocio tres mil años después en su De iure belli ac pacis ${ }^{36}$ bajo el aforismo aut dedere aut punire. La pena correspondiente al delito de rebelión es la ejecución del reo. Incorpora también deberes específicos de asistencia mutua de naturaleza militar frente a las rebeliones. En añadido, se afirma expresamente el derecho a llevar a cabo hostilidades armadas si los rebeldes o desertores reciben materialmente asilo por la otra parte: " $\$ 14$. Si los hititas capturan a este enemigo, lo ejecutarán. Si lo entregan en custodia a Šunaššura, este tendrá la obligación de ejecutarlo. Šunaššura deberá estar en paz con Hatti. Si Su Majestad pide ayuda a Šunašsura, tendrá que restablecerle en el trono. Si los hititas no ejecutan a este enemigo, ni lo entregan en custodia a Šunašsura para que este pueda ejecutarlo, Šunǎšura iniciará las hostilidades contra Hatti siempre que sea capaz de ello" ${ }^{37}$.

\section{Esclavos, cautivos de guerra, poblaciones}

Otras cláusulas de extradición se refieren a huidos que escapan de sus amos, por consiguiente, a esclavos; o a una categoría próxima a estos, los cautivos de guerra, designados con el logograma acadio NAM-RA, "grupos de civiles que son tomados como botín por derecho de conquista tras campañas militares en otros

\footnotetext{
${ }^{33}$ Beckman, Gary M., Hittite diplomatic texts, cit. (n. 1), p. 12.

${ }^{34}$ Tratado entre Šupiluliuma I de Hatti y Huqqana de Hayasa $\$ \$ 15$ p. 18; Tratado entre Šuppiluliuma I de Hatti y Aziru de Amurru, \$9; Tratado entre Šuppiluliuma I de Hatti y Tette de Nuhašse \$8; Tratado entre Muršili II de Hatti y Tuppi-Těšup de Amurru \$12; y Tratado entre Muršili II de Hatti y Niqmepa de Ugarit \$8., BECKMAN, Gary M., Hittite diplomatic texts, cit. (n. 1), respetivamente pp. 26; 35; 52; 57; 62; Tratado entre Muršili II de Hatti y Targašnalli de Hapalla, $\$ 7$ ibíd., p. 66.

${ }^{35}$ Ibíd., p. 18. Aunque por su carácter más fragmentario e incompleto no sea tan claro, el Tratado entre Niqmepa de Alalakh e Ir-Tě̌šup de Tunip (1425 a. C.) puede estar conteniendo cláusulas de este tipo. Véase los $\$ \$ 2$ y 3.

${ }^{36}$ Grotil, Hugonis, De Iure Belli ac Pacis Libri Tres (Carnegie, Institute of Washington, 1913), I, pp. 365, 368-369.

${ }^{37}$ De la versión en acadio, vease también los $\$ \$ 15$ a 17, 23 y 24. En la versión en hitita del tratado, $\$ \$$ 1-10. BECKMAN, Gary M., Hittite diplomatic texts, cit. (n. 1), pp. 16, 17, 21-22.
} 
territorios" 38 , existiendo otros términos también para su designación ${ }^{39}$. Durante su amargo viaje hacia el territorio del nuevo señor ${ }^{40}$ o después de ser reinstalados en nuevos asentamientos, intentaban la fuga en busca de una vida mejor.

a) esclavos

Con respecto a esta tipología de emigrantes, las cláusulas de devolución suelen incorporar obligaciones accesorias como el deber de perseguir y capturar, el modo de proceder al mismo mediante el nombramiento de representantes del señor que ha perdido a su esclavo para que a c tú e n en $s u$ no m b re en el territorio del otro Estado, los precios a pagar por las devoluciones cuando el esclavo ha sido capturado y retenido por alguien del otro Estado a quien se ha solicitado la devolución así como los castigos aplicables a los que ocultaban a los fugados en contra de los deberes asumidos. En el Tratado entre Niqmepa de Alalakh e Ir-Těšu up de Tunip figura una cláusula muy completa: "\$5. Si un fugitivo, o un esclavo o una esclava, perteneciente a mi tierra huye a tu tierra, deberás capturarlo y devolvérmelo. Si alguien lo captura y te lo entrega, entonces lo maniatarás (?) en tu prisión; y cuando su señor lo reclame, se lo entregarás. Si no es posible encontrarlo, deberás proporcionarle [al señor del fugitivo] un representante, que podrá capturar [al fugitive] en cualquier ciudad. En las ciudades en las que no se haya encontrado al fugitivo, el alcalde, junto con cinco testigos, deberá jurarlo ante los dioses, prometiendo al señor del fugitivo lo que sigue: "Si mi esclavo mora entre vosotros, deberéis informarme". Si no están de acuerdo en hacer mi juramento, entonces le devolverán el esclavo [al señor del fugitivo]. Si hace el juramento, (pero) luego localiza a su esclavo [entre ellos], entonces serán considerados ladrones; se les cortarán las manos; y se pagarán 5.000 shéquels de cobre a palacio por él' 41 .

\section{b) cautivos de guerra}

Otros tratados se refieren a la devolución de c a u t ivos de gue r ra huidos. Los NAM-RA formaban parte del botín de guerra del vencedor, una práctica compartida por Hatti, Asiria, Mesopotamia, Egipto y el milenario pueblo israelita ${ }^{42}$. A tenor de los textos internacionales supervivientes, ésta debía ser cuantitativamente la principal razón de la caída en la situación jurídica de esclavitud o servidumbre en el II milenio a. C. del AOM, y un instrumento fundamental en

${ }^{38}$ Beal, Richard H., Making, Preserving and Breaking Peace with the Hittite State, en Raaflaub, Kurt A. (ed.), War and Peace in the Ancient World (Oxford, John Wiley \& Sons, 2007), p. 90.

${ }^{39}$ Véase González Salazar, Juan Manuel, Victimas olvidadas. Observaciones sobre el comportamiento de los hititas con sus prisioneros en la frontera centro-septentrional de su Imperio, en Gerión, 31 (Madrid, 2013), pp. 15-50 y toda la bibliografía en su nota 5.

${ }^{40}$ Bryce, Trevor, Life and Society in the Hittite World (Oxford, Oxford University Press, 2002), pp. 100, 104-106.

${ }^{41}$ Véase nota 17. Más arriba se ha presentado también la cláusula del Tratado entre Idrimi y Pilliya, nota 18.

${ }^{42}$ El esclavo era considerado un bien semoviente. MENDELSOHN, Isaac, Slavery in the Ancient Near East (1898, Oxford, Greenwood Press, reimpr. 1978); ChiRichigno, Gregory C., Debt Slavery in Israel and the Ancient Near East (Shefield, A\&C Black, 1993). 
la política demográfica de los grandes estados. Los cautivos que no eran rescatados pasaban a quedar en situación de esclavitud o servidumbre al servicio de las tierras, los templos, el ejército u otras actividades industriales de la época ${ }^{43}$.

El Tratado entre Šuppiluliuma I de Hatti y Aziru de Amurru señala incluso su origen territorial. Muestra campañas victoriosas previas de Šuppiluliuma que condujeron a la captura y deportación de civiles como botín de guerra: " $\$ 8$. Y sean quienes sean los cautivos de Guerra de las tierras que Su Majestad haya conquistador -cautivos civiles de la tierra de Hurri, cautivos civiles de la tierra de Kinza, cautivos civiles de la tierra de Niya, cautivos civiles de la tierra de Nushashshi-, si algún hombre o mujer entre ellos huye de Hatti y entra en vuestra tierra, no debéis pensar lo siguiente: 'Aunque estoy sujeto al tratado y bajo juramento, no quiero saber nada de esto. Ellos están [...] en mi tierra'. Tú, Aziru, deberás capturarlos. $Y$ devolverlos al Reino de $\mathrm{Hatti}^{44}$. Se llegaba a vaciar localidades enteras de su población, se las prendía fuego y deportaban a sus habitantes en masa hacia Hatti: "Derroté y me apoderé de la ciudad de los Kaškas, que ocupaba la región de la montaña de Ašharpaya. Pero vacié la (región de) la montaña de Ašharpaya [...]”45.

Los cautivos, en los relatos, alcanzan cifras de decenas de miles de civiles, aunque es estas cifras podían tener una función propagandística y no ser del todo rigurosas. Seguramente constituían el botín más valioso de la guerra. Son fácilmente imaginables los intentos para evitar ser hechos cautivos de guerra $\mathrm{o}$ para fugarse durante la larga y penosa marcha que les conducía a lejanas tierras extranjeras ${ }^{46}$. También una vez reasentados en otro territorio, debió ser una constante la búsqueda de cualquier oportunidad para regresar a sus antiguos lares y huir de su nueva condición.

Si se hace una valoración del conjunto de las cláusulas convencionales dedicadas a los cautivos así como de los cruces de cartas oficiales y otros textos, se confirma la idea de que para cualquier gran rey de la época el mantenimiento o incremento de su poder guardaba una relación indisociable con el crecimiento demográfico. El número más abundante de cláusulas de devolución con identificación de los sujetos a extraditar es el de los NAM-RA ${ }^{47}$. La e migra c ión for zos a de los

${ }^{43}$ Sobre las ocupaciones y posición de los NAM-RA véase HoffNer (JR.), Harry A., cit. (n. 5), pp. 68-69, 76, 112, 114,121, 139-40, 164-65, 235, 283-84,304, 309-10, 383, 391, 402, 406, 411; Lorenz, Jürgen; Schrakamp, Ingo, "Our Master! Do not destroy us!" The Fate and Role of Non-Combatants in the Wars of the Hittites, en NADALI, Davide; VIDAL, Joan (eds.), The Other Face of the Battle. The Impact of War on Civilians in the Ancient Near East (Münster, UgaritVerlag, 2014), p. 45; BEAL, Richard H., cit. (n. 38), pp. 94-95; BRYCE, Trevor, Hitite State and Society, en Genz, Herman; Mielke, Dirk Paul (eds.), Insigths into Hittite History and Archaeology (Leuven-Paris-Walpole MA, Peeters, 2011), p. 94. Un estudio amplio sobre el valor fundamental de los cautivos de guerra/esclavos en la economía en el AOM en general, MENDELsohn, Isaac, cit., (n. 42), pp 92-120. Sobre el trato a los mismos, véase en general a GonZÁLEZ SALAZAR, Juan Manuel, cit. (n. 39), aunque no distingue claramente entre cautivos y prisioneros de guerra.

${ }^{44}$ Beckman, Gary M., Hittite diplomatic texts, cit. (n. 1), p. 35.

${ }^{45}$ Anales de Muršili II, KBo. 3, 4 rev. III 43'-44', 63'-65', Lorenz, Jürgen; Schrakamp, Ingo, cit. (n. 43), p. 48.

${ }^{46}$ Hoffner (Jr.), Harry A., cit. (n. 5), p. 164.

${ }^{47}$ Beckman, Gary M., Hittite diplomatic texts, cit. (n. 1): Tratado entre Šuppiluliuma I de Hatti y Tette de Nujashshi (CTH53), \$7, p. 52; Tratado entre Mursilli II de Hatti y Tuppi-Tešsup 
cautivos debió ser un vector determinante de esta política. Las guerras exitosas aportaban gran cantidad de esclavos para las tierras o como soldados para el ejército, seguramente el botín más valioso. En una carta del Rey a Kaššū se habla de la repoblación con 300 grupos de NAM-RA de una ciudad que había quedado despoblada tras los ataques de las tribus Kaškas. Un grupo de NAM-RA equivalía a diez personas ${ }^{48}$. Si la cantidad fuera real, esto supondría así aproximadamente un incremento poblacional de 3000 cabezas procedentes de un botín ${ }^{49}$. Sabemos que la población hitita sufrió un dramático descenso como consecuencia de una larga epidemia durante el reinado de Muršili II (véase infra). La mortalidad catastrófica era otro buen motivo para hacer incursiones de guerra. Las deportaciones y reasentamientos masivos cumplían simultáneamente dos grandes objetivos políticos: i) el mencionado de mantener o incrementar el poder con su tenencia, diseminación por el territorio y explotación; ii) accesoriamente el de debilitar al adversario restándole uno de los factores principales del poderío.

\section{c) pueblos enteros}

Otra de las cláusulas notables de extradición es la que se ocupa de movimientos de poblaciones o ciudades al completo. Son cláusulas distintas a la de los NAM-RA. Un botón de muestra se encuentra en el Tratado entre un Rey de Hatti y Paddatišu de Kizzuwadna: "Si la población de un asentamiento del Gran Rey, incluyendo a sus mujeres, sus bienes, su Ganado grande y pequeño, entra en la tierra de Kizzuwadna, Paddatišu deberá capturarlos y devolverlos al Gran Rey" $"$. El Tratado entre Šuppiluliuma I de Hatti y Aziru de Amurru impide tanto su asentamiento en el territorio de los amorreos como el paso en tránsito: " $\$ 11$. Y si alguna población llega a la tierra de Aziru, y tú, Aziru, utilizas palabras desfavorables ante ellos y les diriges hacia las montañas o a otras tierras, habrás roto el juramento. Debes

de Amurru (CTH 62), \$11, p. 57; Tratado entre Muršili II de Hatti y Niqmepa de Ugarit \$7, pp. 61-62; Tratado entre Muršili II de Hatti y Niqmepa de Ugarit, Tratado entre Muršili II de Hatti y Targašnalli de Hapalla $\$ 13$, p. 68; Tratado entre Muršili II de Hatti y Kupanta-Kurunta de Mira-Kuwaliya, \$27, p. 76; Tratado entre Muršili II de Hatti y Manapa-Tarhunta de la Tierra del Rio Seha, \$4, ibíd., p. 78; Tratado entre Muwattali II de Hatti y Alaksandu de Wiluša $\$ 15$ p. 86.

${ }^{48}$ HoffNer (JR.), Harry A., cit. (n. 5), pp. 112-113. También el documento HKM 37, ibíd., pp. 162-163. En general sobre las políticas de reasentamiento de NAM-RA propias también de Reino Asirio y otras civilizaciones posteriores, BRYCE, Trevor, The Kingdom of the Hittites, cit. (n. 6), pp. 217-219, 222-223.

${ }^{49}$ Las cifras se mueven entre 3000 y 5000 cautivos según campaña. En algún caso hasta 60 mil. Lorenz, Jürgen; SChraKamp, Ingo, cit. (n. 43), pp. 45-46, 48-49. En la doctrina se duda del carácter real de estas cifras tan abultadas. Véase por todos GonZÁleZ SalaZAR, Juan Manuel, cit. (n. 39), p. 18.

${ }^{50}$ BeCKMAN, Gary M., Hittite diplomatic texts, cit. (n. 1), \$5, en pp. 12-13. Cláusulas similares en Tratado entre Šuppiluliuma de Hatti y Tette de Nuhašse, \$10, ibíd., pp. 52-53; Tratado entre Muršili II de Hatti y Niqmepa de Ugarit $\$ \$ 1$ 1, ibíd., p. 62; Tratado entre Hattušili III de Hatti $y$ Ramses II de Egypt, \$12-13, ibíd., en pp. 93-94. 
capturarlos y devolverlos al Rey de Hatti" ${ }^{51}$. Se ha detectado cláusulas similares en otros cuatro tratados ${ }^{52}$.

\section{Cláusulas indeterminadas}

Son varios los tratados que junto con las disposiciones específicas de retorno de algunos de los fugitivos que hasta aquí se han enumerado (políticos, cautivos civiles de guerra, esclavos, pueblos enteros deportados forzosamente o que huyen de una guerra en el extranjero, divisiones del ejército) adjuntan otras genéricas para hu idos sin más precisión. Sería un c o n c e p to r e s to de emigrantes sin autorización para salir del país de residencia. Un ejemplo de cláusula catch all aparece en el Tratado entre Tudhaliya II de Hatti y Šunǎ̌šura de Kizzuwadna. Después de los párrafos relativos a la extradición de refugiados políticos-rebeldes, defecciones de tierras, ciudades o cuerpos del ejército- se completa las obligaciones de extradición con otras que determinan la devolución de los emigrados o desplazados sin más especificación: "\$5. Si un fugitivo de Hatti se dirige a Kizzuwadna, Šunašsura deberá capturarlo y devolverlo a Su Majestad. Pero si alguien esconde a un fugitivo, y lo cobija en su casa, deberá pagar con doce esclavos. Si no puede entregar a doce esclavos, será ejecutado" ${ }^{3}$. Contextualmente parece que se proyectaba sobre cualquier emigrado: esclavos, súbditos, cautivos de guerra, fugitivos de la justicia u otras personas sometidas a la jurisdicción del soberano de la tierra de la que huyen.

Junto con una cláusula de extradición de pueblos al completo, el Tratado entre Šuppiluliuma I de Hatti y Aziru de Amurru contiene varias disposiciones que tienden a facilitar la extradición de cualquier huído de ambos reinos ${ }^{54}$; obligación pareja se estampa en el Tratado entre Š uppiluliuma I de Hatti y Shattiwazza de Mittani ${ }^{55}$; y el Tratado entre Šuppiluliuma I de Hatti y Tette de Nuhashshi contiene otra que se aplica a cualquier súbdito de Nuhashisi presente en Hatti ${ }^{56}$. En este caso aparece después de una cláusula de extradición automática de cualquier NAMRA o de cualquier refugiado político presente en Nuhashshi procedente de Hatti y antes de otra relativa a movimientos de pueblos en su conjunto desde Hatti hacia Nuhashshi. Otra idéntica en su contenido y contextualización se recoge en el Tratado entre Mursili II de Hatti y Niqmepa de Ugarit ${ }^{57}$ y en el Tratado entre Muršili II de Hatti y Targasnalli de Hapalla ${ }^{58}$.

${ }^{51}$ Beckman, Gary M., Hittite diplomatic texts, cit. (n. 1), p. 35.

${ }^{52}$ Ibíd. Tratado entre Tudhaliya II de Hatti y Šunašsura de Kizzuwatna \$4-6, supra nota 18, en 4; Tratado entre Šuppiluliuma I de Hatti y Tette de Nuhašš \$10, ibíd. pp. 52-53; Tratado entre Muršili II de Hatti y Niqmepa de Ugarit, ibíd. \$11, p. 62; Tratado entre Hattušili III de Hatti y Ramsés II de Egipto, ibíd. \$\$ 12 y 14, pp. 93-94.

${ }^{53}$ La cláusula cinco desarrolla la cuestión de la restitución y luego la obligación paralela desde la perspectiva de Šunaššura en los $\$ 7$ a 10. BECKMAN, Gary M., Hittite diplomatic texts, cit. (n. 1), pp. 21-22.

${ }^{54} \$ \$ 12-13$, ibíd., pp. 35-36.

$55 \$ 9$, ibíd., p. 41.

${ }^{56} \$ 9$, ibíd., p. 52.

${ }^{57}$ (CTH 66), $\$ 9$. También $\$ \$ 12$ y 13, ibíd., p. 62.

${ }^{58} \$ 6$, ibíd., p. 66. 


\section{RAZONES PARA LA EMIGRACIÓN EN MASA}

Los tratados no ofrecen la explicación de las razones que podían empujar a las diferentes formas de fuga masiva de población a las que aluden. Únicamente identifican los hechos regulados y forjan la obligación de los Estados de impedir la fuga de pueblos enteros mediante el tránsito por su territorio o de prohibir su establecimiento, procediendo en ambos supuestos a la devolución a su legítimo soberano. Pero otros textos supervivientes (anales históricos, textos literarios, cartas oficiales y mitos) ofrecen información significativa para aventurar hipótesis verosímiles para los casos de emigración en masa. Estos flujos migratorios en masase debieron alternativamente a razones políticociviles o económico-ambientales-económicas, igual que en los tiempos presentes. Con los datos ofrecidos por estos documentos, el libro del Éxodo israelita parece una narración religiosa que parte o integra elementos históricos verificables propios del II milenio a. C.

\section{Politico-civiles}

En los Anales de Muršili II (1321-1295 a. C.), se recogen dos historias que podrían empujar al exilio a poblaciones al completo por razones político-civiles. Los habitantes de una ciudad derrotada van a pasar a la condición NAM-RA. El ejército de su rey ha sido derrotado en campaña por las tropas de Hatti. La ciudad será dada al saco. Su rey ha escapado al exilio poniendo mar de por medio. Toda la población, sabedora de la suerte que les espera, huye también antes de ser capturada: "Uhhaziti no me ofreció ninguna oposición; huyó antes de que llegara y cruzó el mar hacia las islas. Y allí permaneció. Pero toda la tierra de Arzawa huyo" 59 .

Si en su intento de fuga hubieran pasado por el territorio de otro Estado aliado de Hatti, el Gran Rey habría solicitado la captura y extradición de conformidad con los tratados celebrados al respecto. En el mismo texto histórico se explica cómo durante una campaña militar victoriosa del Gran Rey, la mayor parte de las personas de varias ciudades vencidas consiguen huir antes de su captura. Intentan tomar refugio en el Estado de Karkemish del Rey Šarri-Kušuh (o Piyaššili) ${ }^{60}$. Muršili II solicita poder acceder a su territorio para darles captura: "[...] Escribi en los siguientes terminus a Šarri-Kǔsuh [...] Porque los cautivos civiles han huido antes de mi llegada y han tomado refugio en las laderas escarpadas de las montañas (y) no (queda) nada para nosotros (de) la (campaña militar del presente) año, déjanos proceder a rodear a sólo uno de los dos grupos y a llevarlos con nosotros de regreso" ${ }^{61}$.

No disponemos del texto tratado de vasallaje de Šarri-Kušuḩ pero Muršili II renovó el tratado de vasallaje de Karkemish durante su mandato ${ }^{62}$. Sí ha llegado el tratado bilateral de vasallaje/protectorado de Hatti con Šattiwaza, reino colindante.

\footnotetext{
${ }^{59}$ KBo. 3, 4 obv. II 30-33. Lorenz, Jürgen; Schrakamp, Ingo, cit. (n. 43), p. 50.

${ }^{60}$ Piyaššili adopta el nombre hurrita de Šarri-Kušuh al tomar el reino de Karkemish.

${ }^{61}$ KUB 14.15 iii 27-38, duplicado KUB 14.16 iii 3-5), Hoffner (Jr.), Harry A., cit. (n.

${ }^{62}$ Edicto, en BeCKMAN, Gary M., Hittite diplomatic texts, cit. (n. 1), p. 154.
} 5), p. 69. 
Se celebró antes y contiene cláusulas de entrega de fugitivos ${ }^{63}$. Esto permite deducir la existencia de cláusulas de captura y extradición en el otro tratado bilateral de Hatti con Karkemish.

En fin, el \$11 del Tratado entre Mursilli II de Hatti y Niqmepa de Ugarit detalla este caso particular de emigración colectiva sometida a extradición. Regula la fuga de los habitantes de ciudades enteras d u rante el transcurso de una guerra en un territorio extranjero, ante el temordel asedioy captura a que iban a ser sometidas por parte de las tropas. Esos pueblos pasarían a pertenecer también al Rey de Hatti y no podían asentarse en el territorio de Ugarit: "Si la población de alguna tierra extranjera oprimida por la batalla se establece y entra en la tierra de Ugarit, Namepa los tomará y los entregará al Rey de Hatti" ${ }^{64}$.

\section{Económicas y medioambientales}

Además de la guerra, otros textos ofrecen abundantes razones para proceder a la emigración masiva. Estas serían de naturaleza económica y medioambiental, indisociablemente unidas por la vinculación directa de la economía con el medioambiente en el Bronce Tardío. Las catástrofes naturales entorpecían gravemente los modos de subsistencia tradicional de distintos grupos humanos asentados en un territorio y les impelía a desalojar su ubicación en búsqueda de territorios con mejores condiciones.

\section{a) carestía}

Es sabido que los hititas llegaron a construir grandes silos para el almacenamiento de las cosechas ${ }^{65}$. Su existencia indica la frecuencia de períodos de sequía y carestia que podía estar en la base de los flujos migratorios de la época. $\mathrm{Al}$ parecer el período que va del 1500 al 1300 a. C. en el AOM fue mucho más húmedo y productivo que durante el siglo posterior. Este cambio climático $-\mathrm{u}$ otras irregularidades climatológicas- debió originar grandes movimientos de población, entre otros, de los pueblos nómadas o seminómadas cuya vida dependía completamente del medio natural. Los "años de hambre" como se citan en los textos hititas ${ }^{66}$ conducían a altas tasas de mortandad ${ }^{67}$. En ocasiones, esa escasez alimentaria hizo también que tuvieran que recurrir a la importación de grano de Siria y Egipto ${ }^{68}$. Los períodos de escasez son referidos en el libro del Génesis como la razón crucial de los movimientos recurrentes de las tribus hebreas. Y también se menciona la construcción de silos. Así, la narración religiosa del Antiguo Testamento confirmaría lo que aparece en los tratados y otros textos hititas, y en sentido inverso, los textos hititas probarían el carácter histórico y no únicamente religioso de aquel texto sagrado.

\footnotetext{
${ }^{63}$ Véase nota 21.

${ }^{64}$ Beckman, Gary M., Hittite diplomatic texts, cit. (n. 1), p. 62.

${ }^{65}$ HKM 18: 21-28, l.e. 1-5, en HoffNer (JR.), Harry A., cit. (n. 5), p. 128.

${ }^{66}$ HKM 8, HKM 19, HKM 24, HKM 50, HKM 80 y (Bo 2810), ibíd., pp.108, 137,

$139,188,340$ y 363 .

${ }^{67}$ Ibíd., pp. 65 y 222.

${ }^{68}$ Ibíd., pp. 65-66.
} 
Emerge por primera vez en la migración de la tribu de Abrahán, el primer patriarca hebreo. Según el relato del Génesis, cuando sobreviene una carestía, Abrahán decidió abandonar Canaán y trasladarse a Egipto ${ }^{69}$. Tambíen es porque "en Canaan aprieta el hambre"70 que la luenga tribu de Jacob/Israel se traslada desde Canaán a Egipto, "la región de Ramsés"71. La construcción de silos en Egipto es atribuida precisamente a las instrucciones de José, el hijo predilecto de Jacob/Israel que viene de las tierras de Canaán, territorio amorreo sometido a los hititas. Aparece en el episodio de la interpretación de los sueños del Faraón: las siete vacas flacas y mal alimentadas que se comieron a las siete vacas hermosas y bien cebadas; las siete espigas hermosas y granadas que son devoradas por otras siete secas y negres son sietes años de abundancia seguidos por otros siete de esca$\mathrm{sez}^{72}$. José es nombrado Gran Visir del Faraón y ordena construir un g r a n e r o para guardar excedentes de las cosechas de los períodos de abundacia que serán utilizados en los de vacas flacas.

\section{b) plagas y epidemias}

A la luz de los textos hititas, tampoco la plaga de langostas a la que alude el libro del Éxodo o la gr a n e p id e m i a que asola Egipto sería estrictamente un relato de fantasía. La Carta del Rey a Kaššu y Pulli menciona la existencia de una plaga de langostas y los graves daños para la cosecha de la tribu vecina de los Kaskas. Por ese motivo, el pueblo Kaska sale de sus tierras e invade el territorio hitita para adueñarse de sus cosechas ${ }^{73}$. Kaššū y Pulli habían solicitado asistencia militar al rey.

En nueve textos más se hace referencia a e p i d e m i a s que habrían diezmado peligrosamente la población hitita. Buen motivo también para abandonar en masa una ciudad. Se dispone por un lado de dos cartas dirigidas al rey por sus delegados territoriales en las que se informa de la existencia de epidemias locales y la muerte de la población ${ }^{74}$. De otro, el grupo más significativo de textos es el conjunto de himnos y plegarias dirigidas por el Rey Muršili II a diferentes deidades relativas a una gran epidemia que asolaba Hatti ${ }^{75}$. En el "Himno de Muršili y oración a la diosa del sol de Arinna” el rey pide que algún profeta reciba el mensaje de los

${ }^{69}$ Génesis 12-10.

${ }^{70}$ Génesis 47.

${ }^{71}$ Génesis 47-11.

${ }^{72}$ Génesis 41.

${ }^{73}$ Hoffner (Jr.), Harry A., cit. (n. 5), pp. 129-130.

${ }^{74}$ Ibíd., pp. 183 y 187.

${ }^{75}$ Himno de Muršili y oración a la Diosa del sol de Arinna; Himno de Muršili y oración a Telipinu; "Tercera" oración de la plaga de Muršili a la diosa del sol de Arinna; "Segunda" Oración de la Plaga de Muršili al Dios de la Tormenta de Hatti; "Primera" Oración de la Plaga de Muršili a la Asamblea de Dioses y Diosas; "Cuarta" Oración de la Plaga de Muršili a la Asamblea de Dioses; "Quinta" Oración de la Plaga de Muršili a la Asamblea de Dioses, traducción a partir de Singer, Itamar, Hittite Prayers (Atlanta, Societal of Biblical Literature, 2002), pp. 49-69. Otras traducciones de las plegaries al español en García Trabazo, José Virgilio, Textos religiosos hititas: Mitos, plegarias y rituales (Madrid, Trotta, 2002) y BernABÉ, Alberto, Textos literarios hetitas ${ }^{2}($ 1979, Madrid, Alianza Tres, 1987). 
dioses con la explicación de las razones de su cólera; o que los dioses revelen al pueblo su voluntad a través de los sueños: "\$6 Oh, dioses, ¿qué habéis hecho? Habéis dejado entrar una plaga en Hatti, y todo Hatti está muriendo [...] $\mathbb{S} 7$. [...] Oh, dioses, sea cual sea nuestro pecado, dejad que venga un hombre de dios [y lo declare], o que las ancianas [las adivinas o los auguries lo determinen], o que las personas corrientes lo vean en sueños [...] Por un lado nos oprime la plaga, [y por el otro] nos oprimen las hostilidades [...] S 9. Y ahora, todas las tierras de los alrededores han empezado a atacar Hatti. Dejad que esto se convierta en otro motivo de venganza para la Diosa sol de Arinna"76. Tópicos culturales todos ellos recogidos también en múltiples apartados del Pentateuco como el citado de la interpretación de los sueños por José el Egipcio.

En la oración dirigida a Teššup, dios de la tormenta, Muršili II asocia los veinte años de epidemia que asolan su reinado con el castigo de los dioses por la vulneración previa de un tratado internacional entre Hatti y Egipto, atribuida a su padre, Šuppiluliuma I. Teššup había sido puesto como garante del Tratado. El incumplimiento de los juramentos prestados ante los dioses es la causa del castigo expiatorio y el rey trata de encontrar el modo de reparar el daño hecho: "[...] Dado que los hombres de Hatti y los hombres de Egipto estaban vinculados por el juramento al Dios de la tormenta de Hatti, y lo hombres de Hatti procedieron a intentar dominar, los hombres de Hatti, repentinamente, quebraron el juramento a los dioses. Mi padre envió la infantería y los carros de combate, y atacaron las tierras fronterizas de Egipto, la tierra de Amqa. Y otra vez los envió, y otra vez atacaron [...] Cuando encontré en la tabla referida en la que se contienen las relaciones con Egipto, pregunté sobre la misma a el dios a través de un oráculo diciendo: " Nos ha traido el Dios de la tormenta de Hatti estas desgracias porque los hombres de Egipto y los hombres de Hatti estaban ligados mediante un juramento hecho prestado ante el Dios de la Tormenta de Hatti? [...] $Y$ fue confirmado por el oráculo [...] Continuaré removiendo las causas de la plaga tal [...] continuaré realizando las restituciones pertinentes. Con respecto al problema del juramento a los dioses que ha sido fijado como causa para la plaga, he ofrecido el ritual de expiación [...]" 77 .

En otra plegaria el rey angustiado cree que la causa de todos los males podía estar en la ruptura de otro juramento. Šuppiluliuma I, su padre, arrebató el trono de modo ilegítimo a su hermano, el Rey Tudhaliya, al que asesinó o mandó asesinar ${ }^{78}$.

\section{EJECUCIÓN DE LAS OBLIGACIONES DE EXTRADICIÓN Y IUS AD BELLUM}

Otra conclusión que se deriva de los textos es la conexión entre el cumplimiento de la obligación de captura y extradición de los emigrados de una u otra naturaleza con el mantenimiento de las relaciones de relaciones de paz y buena vecindad entre los reinos implicados. En las fuentes hititas la no devolución de los emigrantes reclamados por un soberano a

\footnotetext{
${ }^{76}$ Ibíd., pp. 51-53.

77 "Segunda" Oración de la Plaga Muršili al Dios de la tormenta de Hatti, ibíd., pp. 58-59.

78 “Primera” Oración de la Plaga de Muršili a la Asamblea de Dioses y Diosas, ibíd., pp. 61-62.
} 
otro se menciona en varias ocasiones como una causa justa para recurrir a la guerra. En términos jurídicos latían dos controversias jurídicas diferentes que $\mathrm{j} u \mathrm{~s}$ t i f i c a b a $\mathrm{n}$ el recurso lícito a la guerra: a) la alegación por una parte del incumplimiento por la otra de obligaciones de devolución de exiliados fijadas en los $\mathrm{tr}$ at ados; b) o, en ausencia de tratados bilaterales, la existencia de un conflicto de jurisdic c i o n e s, jurisdicción personal versus jurisdicción territorial, que podían invocarse como válidas para afirmar el poder sobre una persona; c) la guerra resolvía válidamente quién tenía mejor derecho entre las partes enfrentadas. Emergen así las primeras racionalizaciones del ius ad bellum.

a) reclamación del cumplimiento de las obligaciones convencionales

Varios textos atestiguan la existencia de un procedimiento diplomático estándar para obtener la extradición de fugitivos ligada al cumplimiento de un tratado. Mediante cartas el soberano reclamaba por escrito el cumplimiento de las obligaciones de extradición. De la satisfacción de la reclamación dependían las relaciones entre ambos reinos.

El más antiguo es el borrador de carta diplomática de Acusación a Madduwatta por Arnuwanda I de Hatti ${ }^{79}$. El documento contiene un conjunto de acusaciones del Rey de Hatti a Madduwatta, un gobernador o rey vasallo. Se alude claramente al incumplimiento de múltiples obligaciones fijadas mediante tratado. El $\$ 6$ de la misiva señala la existencia de una obligación de extradi c i ón de cualquier fugado de Hatti que llegue a las tierras de Madduwatta fijada mediante un tratado. El $\$ 22$ contiene la p rotest a formal por el incumplimiento de esta obligación y la intimación reiterada a la satisfacción del deber pendiente. La respuesta a la pretensión no podía ser una evasiva: "Tú, Madduwatta, sigues reteniendo a los fugitivos de Hatti que han [llegado] a ti. [El padre] de Mi Majestad y Mi Majestad te han escrito sobre ellos en varias ocasiones, pero tú sigues sin entregárnoslos. [Y] te hemos escrito [...] sobre este asunto, pero no hemos recibido respuesta en tu defensa sobre esta cuestión. [Y] tú [nos escribes] sobre otros temas. Siempre nos das respuesta sobre otros temas" ${ }^{80}$. Más adelante se hace referencia al envío de un diplomático portador de otra solicitud de extradición de un c a z a d o $r$ fugado, también rechazada $^{81}$. El texto superviviente está inacabado y no se sabe más sobre cómo se resolvió la controversia. Todo él muestra una gran indignación por la conducta de Madduwatta.

La Carta de Hattušili III a Bentešina contiene otra solicitud por escrito de entrega de un fugitivo político. Bentešina, el rey de los amorreos, fue restaurado en el poder por Hattušili III y había quedado sometido a su vasallje por un tratado $^{82}$. La misiva exige a Bentešina el cumplimiento de su obligación de hacer

\footnotetext{
${ }^{79}$ Beckman, Gary M., Hittite diplomatic texts, cit. (n. 1), pp. 144-151.

${ }^{80}$ Ibíd., p. 149.

${ }^{81}$ Ibíd., pp. 150-151.

${ }^{82}$ Explicación histórica en $\$ \$ 2-5$ Tratado entre Hattušili III de Hatti y Bentešina de Amurru, BeCKMAn, Gary M., Hittite diplomatic texts, cit. (n. 1), pp. 95-98.
} 
todo lo posible para capturar y extraditar al "enemigo de Su Majestad": "Respecto a lo que me escribiste: 'En cuanto al enemigo de Su Majestad, mi señor, no sé si está en la tierra de Egipto o en otra tierra', „captúralo (y) entrégamelo" ${ }^{93}$.

El \$1 Tratado entre un Rey de Hatti y Paddatišu de Kizzuwadna deja constancia del mecanismo que se aplicaba para resolver una alegación en contra de la obligación de extraditar. El tratado recoge el procedimiento de la entrega de la carta con la solicitud de extradición a través de un enviado diplomático. ¿Qué pasaba si la persona cuya extradición negaba los cargos de rebelión?: "-Si la acusación es cierta, el fugitivo deberá ser extraditado. Pero si el fugitivo lo niega, afirmando: "Yo no me he rebelado contra él", sus palabras serán consideradas falsas. Paddatišu puede preguntar a cualquier hitita de confianza [¿nobles?] para que preste su juramento sobre esto y si lo hace, el fugitivo será extraditado" ${ }^{44}$. Es decir, la palabra del rebelde cuestionando los cargos formulados por el enviado del rey pierde todo valor probatorio frente al j u r a m e n to de los nobles mensajeros diplomático del rey que exigía su extradición.

De los Anales de Muršili II llega un relato que recoge aquel caso particular de ejecución de la obligación de captura. Muestra cómo podía acabar la opción de ejecución de la obligación alternativa aut dedere aut punire. Muršili II de Hatti había solicitado a los gobernadores de dos ciudades que le entregaran a dos sediciosos, esto es, pers on as que hablaban mal del Gran Rey de Hatti. Los habitantes, tomaron la decisión de ejecutar ellos mismos a los fugitivos por el miedo a ser atacados ${ }^{85}$.

\section{b) incumplimiento de obligaciones fijadas por tratado}

En el sistema jurídico internacional del AOM la vulneración de un tratado era una causa justa para el recurso a la guerra ${ }^{86}$. Esta norma se a plicaba también al incumplimiento específico de los deberes de captura y extradición fugados por un tratad. Esto realza su carácter esencial en la alianza.

Se ve ya en el preámbulo del Tratado entre Tudhaliya II de Hatti y Šunaššura de Kizzuwadna ${ }^{87}$. En los primeros párrafos se relata la negativa del rey de los hurritas a devolver a ciertos súbditos de Hatti huidos tras una rebelión. Luego recoge la toma de cautivos por el rey mitano en el territorio de Hatti. El texto califica la acción de no devolver a los refugiados políticos y a los cautivos como una vulneración del tratado en vigor entre ambos. Se refiere elípticamente aludiendo

${ }^{83}$ SINGER, Itamar, The Urhi-Tessub affair in the Hittite-Egyptian Correspondence', en VAN DEN Hout, Theo P. J. (ed.), The Life and Times de Hattusili III and Tuthaliya IV. Proceedings of a Symposium held in Honour of J. De Roos, 12-13 December 2003 (Leiden, Nederlands Instituut voor het Nabije Oosten, 2006), p. 33.

${ }^{84}$ Beckman, Gary M., Hittite diplomatic texts, cit. (n. 1), p. 12. También $\$ 6$.

${ }^{85}$ Lorenz, Jürgen; Schrakamp, Ingo, cit. (n. 43), pp. 37 y 53.

${ }^{86}$ BEAL, Richard H., cit. (n. 38), p. 89; y BeLl, Lanny, Conflict and Reconciliation in the Ancient Middle East: The Clash of Egyptian and Hittite Chariots in Syria, and the World's First Peace Treaty among 'Superpowers', en RaAflaub, Kurt A. (ed.), War and Peace in the Ancient World (Oxford, John Wiley \& Sons, 2007), pp. 98-120.

${ }^{87}$ BeCKMan, Gary M., Hittite diplomatic texts, cit. (n. 1), p. 13. 
a la vulneración del j u r a m e n t o, modo tradicional de concluir los tratados de la época. El rey hurrita alega que los huidos eran antiguos súbditos suyos que se habían fugado anteriormente hasta Hatti. Fijados los términos jurídicos de la controversia y siendo las pretensiones irreconciliables, la guerra fue el instrumento legal para castigar y obtener una satisfacción por el ilícito internacional previo ${ }^{88}$.

El Tratado entre Šuppiluliuma I de Hatti y Huqqana de Hayasa ${ }^{89}$ contiene también una referencia directa al uso de la guerra como sanción al incumplimiento de las obligaciones de extradición de refugiados políticos. Los $\$ \$ 15$ a 17 establecían una alianza entre las partes frente a revueltas internas. El \$18 exigía que en cualquier momento que Huqqana oyera de la existencia de cualquier trama o complot urdido desde el exterior para su derrocamiento, si el soberano lo encubría o daba cobijo al sedicioso, en lugar de proceder a informar de la situación y a la entrega del traidor, los “dioses le destruirán”.

La regla general era que la vulneración de los juramentos prestados conducía a la destrucción del infractor a través de la guerra sancionada por los dioses. Así, la necesidad de dotar de un carácter legítimo o justo a las guerras era un tópico recurrente en este período analizado del II milenio a. C. en el $\mathrm{AOM}^{90}$. En la visión deontológica hitita, egipcia, siria, etc., como miles de años más tarde en el ius publicum europaeum, la guerra era concebida como un instrumento justo para resolver una disputa jurídica ${ }^{91}$ tras satisfacer la regla procedimental de la i n t i m a c i ó n o requerimi en to de la conducta que una parte consideraba ajustada a derecho, y recibir el r e chazo explíc i t o -por escrito a través de intercambios de cartas diplomáticas- o implícito - la no contestación a las peticiones-a la reclamación. El resultado de la guerra determinaba la justicia de la reivindicación jurídica previa que motivaba el recurso a las armas. El razonamiento dogmático que conduce a esta idea normativa es el mismo que figurará en los orígenes del derecho internacional clásico. La voluntad divina, garante del tratado puesto que se ratifica mediante juramento ante los dioses, y no los ejércitos en concreto que libraron la batalla, era la que decidiría la suerte de la contienda y el mejor derecho en la controversia jurídica original. La gue r ra, un a forma específia

88 "Cuando el pueblo de la tierra de Isuwa, súbditos de Mi Majestad, iniciaron las hostilidades contra Mi Majestad, yo, Mi Majestad, me enfrenté a ellos. Derroté a la tierra de Isuwa y sus habitantes huyeron hacia la tierra de Hurri. Entonces, yo, Mi Majestad, le envié esta misiva al soberano de Hurri: “Devuélveme a mis súbditos!”. Pero el soberano de Hurri me contestó: “;No!”. Antiguamente, en tiempos de mi padre, la población de estas ciudades se instaló en Hurri. Y luego, en efecto, se asentaron como fugitivos en Hatti. Ahora finalmente, el ganado ha escogido su establo. Ha venido a mi tierra de modo definitivo. El soberano de Hurri no devolvió mis súbditos a Mi Majestad, sino que envió a la infantería y los carros de combate. En ausencia de Mi Majestad, saquearon la tierra de Isuwa. Llevaron a la tierra de Hurri a todos los civiles cautivos, bueyes y ovejas que capturaron, mientras yo, Mi Majestad, permanecia en el campo de batalla luchando contra otro enemigo. El soberano de Hurri rompió el juramento [...]” \$\$3, ibíd., pp. 14-15.

${ }^{89} \$ 18$, ibíd., pp. 22-29.

${ }^{90}$ Con respecto al Imperio Asirio y a Israel, Crouch, Carly L., War and Ethics in the Ancient Near East (Berlin-New York, de Gruyter, 2009).

${ }^{91}$ Lorenz, Jürgen; SchraKamp, Ingo, cit. (n. 43), p. 39; Beal, Richard H., cit. (n. 38), pp. 89-90; BECKMAN, Gary M., International Law, cit. (n. 20), p. 769. 
de ordalía entre Estados, era el modo específico de determinar el sentido inmanente de la justicia divina en una controversia jurídica concreta no resuelta por medios diplomáticos entre soberanos. Como en los orígenes del derecho internacional público europeo. Ante los dioses juraron, los dioses decidirán quién es el perjuro arrebatándole la victoria.

\section{c) conflicto de jurisdicciones}

Tres textos ejemplifican otra variante del recurso a la guerra como método de solución de controversias relativas a los fugitivos. En ninguno se alude a la vulneración de los j u r a m e n t o s lo que hace pensar que no había obligaciones convencionales previas. Sin embargo, el soberano de Hatti reclama el ejercicio de su jurisdicción ratione personae contra los $\mathrm{s} u$ b d it os huidos presentes en el territorio de otro soberano. El rechazo de esta pretensión era invocado por Hatti como causa justa para la guerra que resolvería la disputa jurisdiccional.

Según los Anales de Muršili II, sus tropas habían marchado contra las ciudades rebeldes de Attarimma, Huwarsanassa y Suruda. Los gobernadores de las ciudades, junto con parte de sus tropas, huyeron y tomaron refugio en el reino colindante de Arzawa. Muršili II pidió a Uhha-Ziti, Rey de Arzawa, que se los entregara. La negativa a su extradición motiva el recurso a la guerra. No se invoca la existencia de ningún tratado previo que creara una obligación de devolución así que no se trataría de dar aplicación a los deberes de un tratado en vigor, si no de resolver una pretensión jurisdiccional genérica ${ }^{92}$.

La denegación formal del petitum, en este caso, el rechazo a la pretensión del ejercicio de los poderes personales de un rey sobre sus súbditos y la afirmación de la jurisdicción territorial propia sobre los extranjeros presentes en el territorio, desata la gue r ra ju sta según la posición del Reino de Hatti.

Otro pasaje similar surge de la correspondencia de Muršili II con el Rey Pihhuniya de los Kaškas. En este caso, el grupo seminómada de los Kaškas había conseguido atacar con éxito una parte de los dominios de Hatti. Como parte del botín de guerra se había llevado cautivos a súbditos hititas. Muršili II reclama sin éxito al Rey Pihhuniya su devolución. Para Hatti el súbdito o esclavo era considerado un bi en s e m ovi e n t e que se había desplazado ilegalmente a otro territorio. Recordemos el preámbulo histórico citado antes del Tratado entre Tudhaliya II de Hatti y Šunašsura de Kizzuwadna que asimila metafóricamente a los emigrantes con el ganado: "Ahora, finalmente, el ganado ha elegido su establo. Definitivamente han venido a mi tierra". Por su parte, el soberano que acogía, asentaba o daba asilo a los emigrados podía invocar a su favor la competencia exclusiva para el ejercicio de su jurisdicción con respecto a todo cuanto aconteciera

${ }_{92}$ "Pero a Uhhaziti le envié un mensajero y le escribi: "Mis súbditos, que han acudido a tí, te he pedido que me los devuelvas, y no me los has devuelto. Ytambién me has llamado niño y me has menospreciado. Así, jalcémonos ahora! ‘El uno contra el otro! Y el Dios de la tormenta, mi Señor, decidirá la controversia por nosotros.' (KBo. 3, 4 obv. II 9-14), en LORENZ, Jürgen; SCHRAKAMP, Ingo, cit. (n. 43), p. 40; BEAL, Richard H., cit. (n. 38), p. 90. 
dentro de los límites de su territorio y tomar libremente, por ello, la decisión sobre la entrega o no del extranjero. El escrito tampoco invoca como causa de la guerra la vulneración de un tratado o de juramentos previos. La pretensión del Reino Hitita y de su oponente es general ${ }^{93}$.

La legítima defensa a la que alude Pihhuniya le habilitaba para no esperar el primer golpe en sus propias tierras y reprimir un ataque en curso violando las fronteras del adversario armado. El conflicto político debía ser muy severo si se prestaba asilo a un rebelde.

En fin, ha llegado una Carta de Hattušili III al Rey de Ahhiyawa que sugiere que realmente la regla de extradición de refugiados políticos no se habría consolidado como una obligación general en ausencia de tratados. Se trataría más bien de una política de fuerza impulsada por el Gran Rey de Hatti bajo la amenaza de su poderío militar y que querría transformar en una obligación jurídica general. El rey hitita se queja de que el Rey de Ahhiyawa puede estar dando apoyo a Piyamaradu, un rebelde huido de los dominios de Hatti que aprovechaba el refugio obtenido en la tierra de Ahhiyawa para llevar a cabo desde este territorio acciones armadas contra Hatti. Le pide que se lo envíe o que lo expulse de su territorio ${ }^{94}$.

De nuevo, la carta no cita la existencia de ninguna obligación convencional de extradición. El tono es moderado. No se sabe si el Rey de Ahbुiyawa satisfizo la petición. Las acciones de Piyamaradu debilitaban la región occidental de Hatti aumentando su influencia sobre la misma ${ }^{95}$. Así, en ausencia de obligaciones convencionales la extradición entre iguales parecería más un acto amistoso que una obligación, y era manejado a discreción. Si es así, aunque dar asilo, refugio o aceptar simplemente su asentamiento a cualquier extranjero que entrara en sus dominios pudo ser entendido como una competencia territorial soberana que podía reportaba ciertas ventajas ${ }^{96}$, evitar ataques o incursiones de otros Estados vecinos hegemónicos, o su simple enemistad, jugaba en contra de su ejercicio. En especial, en casos de gran disparidad de fuerzas. La independencia política y otras posibles ventajas prácticas que podía implicar conceder hospitalidad a personas en busca de asilo o refugio entrañaba riesgos ciertos para quien la ejerciera.

93 "Yo, Mi Majestad, me dirigi a él, le envie a un mensajero y le escribi: "Devolvedme a mis súbditos, los que habéis capturado y enviado a Kaška". Pero Pihhuniya me contestó diciendo: "No voy a devolverte nada. Y si vienes librando batalla, bajo ningún concepto haré la guerra en mi propia tierra, me dirigiré a tu (propio) pais, y alli libraré batalla contra ti” [...] me enfrenté a él en una batalla", KBo. 3, 4 rev. III 76'-85, LORENZ, Jürgen; SCHRAKAMP, Ingo, cit. (n. 43), p. 41.

94 "Según este rumor, durante el tiempo en que ha dejado a su mujer, sus hijos y su casa en la tierra de mi Hermano, tu tierra le ha ofrecido protección. Pero él, está atacando constantemente mi tierra; cada vez que lo evito, él regresa a tu territorio. ¿Estás dispuesto, Hermano, a consentir esta conducta? (Si no), hermano, escríbele por lo menos esto: "Levántate, dirígete a la tierra de Hatti. ;Tu señor ya ha ajustado las cuentas contigo! De lo contrario, ve a la tierra de Abhiyawa, y en cualquier lugar en el que te instale, [debes permanecer allí] [...] Mientras estés enemistado con el rey de Hatti, iejerce tus hostilidades desde (cualquier) otro país! Desde mi país no debes conducir las hostilidades!". BRYCE, Trevor, The Kingdom of the Hittites, cit. (n. 6), p. 292.

${ }^{95}$ Ibíd., pp. 292-293.

${ }^{96}$ Galvin, Garret, cit. (n. 18), p. 18; Westbrook, Raymond, Personal Exile, cit. (n. 29), p. 320 . 
La guerra contra otro Estado por la denegación del requerimiento de extradición de un súbdito, en ausencia de tratados, sería en estos casos una decisión política que se quería transformar en derecho por la vía de la coacción. La amenaza potencial o su materialización ocasional debía hacer más fácil también que el Reino de Hatti transformara su política poblacional expansiva en acuerdos internacionales que obligaban a los reinos circundantes a devolver súbditos, cautivos de guerra o esclavos huidos sin reciprocidad. Entre el vasallaje o la plena subyugación y anexión por la fuerza, se escogía el mal menor salvo que se obtuviera la tutela de otra Gran potencia que propusiera otras asimetrías más convenientes circunstancialmente. Sólo cuando las fuerzas eran equiparables, como en el caso del Tratado de Qadesh, las obligaciones eran iguales. Aquí la extradición simplemente ayudaba a eliminar fricciones futuras por la jurisdicción sobre los nobles, súbditos o esclavos en fuga de los reinos respectivos. Hatti, no se ha de olvidar, como regla general no extraditaba a ningún inmigrante en los tratados de alianza desiguales.

\section{Conclusiones}

Los tratados bilaterales del II milenio a. C. del AOM regulaban inter alia todo tipo de flujos migratorios. Reflejan así la enorme importancia política y económica que otorgaron los Estados a la cuestión demográfica.

Cuando se trata de fenómenos migratorios no políticos, el fundamento de las normas de captura y extradición era el valor esencial de la población para la conservación o crecimiento de los grandes estados territoriales del II Milenio a. C. en una fase demográfica mundial caracterizada por las altas tasas de mortalidad ordinaria o catastrófica. Las acciones básicas para cumplir con esa política demográfica expansiva eran retener todo flujo hacia dentro de migrantes, tomar el mayor número de cautivos civiles como botín de las guerras que se libraban en el exterior, y evitar la emigración. La economía agrícola y militar estaba necesitada de una mano de obra abundante. Desde entonces hasta ahorase ha pasado de una población mundial de entre treinta y cincuenta millones de seres humanos con un crecimiento muy lento, a otra camino de los ocho mil millones en el que las pautas demográficas son muy dispares en función del espacio al que nos refiramos.

Los Estados postindustrializados, el mundo occidental, los grandes Estados en términos de poderío, viven en una fase demográfica moderna con crecimiento de población prácticamente nulo, aunque por razones opuestas a las del régimen demográfico del II Milenio a. C.: las tasas de natalidad están en mínimos históricos lo que hace que el crecimiento de la población sea nimio. Por el contrario, en los países menos desarrollados las tasas de natalidad se mantienen muy altas y los índices de mortalidad están descendiendo gracias a las mejoras sanitarias. ¿Qué señalan así las severas restricciones a los flujos migratorios propias de la UE, los EEUU, y otros países desarrollados de la actualidad en contraste con las políticas demográficas expansivas del AOM? L a pérdida de rentabilidad económica y social de la mayor parte de los seres humanos dentro de los modelos económicos 
contemporáneos. Así, sólo un cambio que devuelva el valor socio-económico a la vida humana simultánea o alternativamente en los lugares de origen o destino de los migrantes, alterará los régimenes normativos migratorios contem poráneos.

La industrialización general de la economía -inclusive la agrícola- así como la incorporación acelerada de las TICs a los procesos económicos y sociales esenciales (producción, distribución, comercialización de bienes, administración pública) hace que, para todos los países, ricos y pobres, los c o s tes s o c i a les asociados a la retención de la población poco cualificada sean superiores a su r e n t a b i lidad s o ci a l agregada. De ahí que los países más desarrollados limiten al máximo la entrada de población migrante. Es un factor que simplemente debe asegurar la tasa de crecimiento poblacional próxima a cero que permite el sostenimiento de su economía y sistema de protección social. Por ello también los países menos desarrollados, con tasas de crecimiento poblacional positivo y costes sociales crecientes, no albergan tampoco un interés real en retenerlos, a diferencia de aquellos tiempos prístinos de la civilización. Sólo cuando se trata de capital humano más cualificado, potencialmente más rentable en términos sociales, las reglas de inmigración de los países desarrollados se vuelven más permeables a su captación y retención. Aquí, aunque pueda haber interés en los estados de origen para retener a esta parte de la población, carecen de los instrumentos materiales ni jurídico-internacionales para hacerlo. El resultado final de esta política migratoria de los grandes estados es la misma que en el AOM: los estados poderosos refuerzan su predominio económico y político a costa de los estados menores, aunque esto se consiga con un sistema normativo opuesto a aquél.

Varios tratados hacen también referencia explícita s a los $\mathrm{r}$ e fu g i a d o s p o lít i c o s. La obligación de captura y extradición de estas personas que buscaban asilo, incluso la regla más compleja aut dedere aut punire, tiene un fundamento distinto. Se trata de la solución jurídica óptima para asegurar las relaciones de paz y amistad entre los estados implicados. Dar refugio a personas que buscan asilo por graves ofensas políticas cometidas contra otro soberano fue calificado como un ilícito internacional muy grave en presencia de cláusulas convencionales de extradición. Y un acto inamistoso u hostil en su ausencia. Los Estados territoriales no tenían discrecionalidad para castigar o perdonar los delitos cometidos por las personas que afectaban a otra comunidad social vecina. Renunciaron a ella a través de tratados bilaterales. Todos los estados del AOM afirmaron su derecho a requerir la captura y extradición, o el castigo, de las personas que habían ofendido su soberanía y huido fuera de sus fronteras, un derecho que consideraban esencial para su dignidad y seguridad como soberanos. Los tratados de alianza consolidaron este derecho. Hoy, como entonces, los procesos de extradición están regulados esencialmente a través de tratados bilaterales. Sin embargo, en los tratados bilaterales de extradición por la comisión de delitos suelen quedar excluidos lo delitos políticos puros (traición, sedición, conpiración, etc.) que fueron especialmente perseguidos en los tratados del II milenio a. C.

Situados propiamente en un marco convencional bilateral, para uno u otro tipo 
de movimiento migratorio, la no extradición de un fugado pasaba a ser claramente considerada como contraria a los juramentos prestados ante los dioses: un acto ilícito internacional gravísimo. La guerra -o las incursiones de apresamiento en los territorios del soberano que había dado acogida a los desplazados- era un instrumento legítimo para la recuperación de las p ropiedades o súbditos en fuga expresamente recogido en los propios tratados. El resultado de la guerra designaba quién disponía el mejor derecho en la causa y quién había vulnerado su palabra poniendo a los dioses por testigo. Los textos muestran un conjunto de normas configuradoras del ius ad bellum idénticas a las que nos encontramos en los albores del derecho internacional público europeo: a) se i n v o c a la existencia de unos hechos contrarios a obligaciones, la justa ca us a b) se in t i m a al cese del hecho injusto; c) si no se obtiene la interrupción, se recurre a la guerra para obtenerelcese de la conducta-devolución de los refugiados-; reparar el daño recibido -el botín de guerra-; y castigar la vulneración -en ocasiones, el derrocamiento del rey a quien se imputa la conducta ilícita y su sustitución por una línea sucesoria distinta de su misma familia-.

Esta identidad normativa son un indicio de la posible influencia del derecho internacional del AOM en el ius publicum europeum, aunque estén separados por más de dos mil años de historia. La conjetura es que las categorías normativas del II milenio $a$. C. habrían pasado al ius publicum europeum a través del $A T$, en especial del Pentateuco, una de las fuentes esenciales de conocimiento para la escolástica (Agustín, Tomás de Aquino), la neoscolástica española (Vitoria, Las Casas, Suárez) y también del pensamiento absolutista (Grocio). Se ha mostrado aquí cómo a través de estos textos llegan fenómenos históricos y tópicos culturales de aquella época. ¿También lo hicieron los normativos? La regla aut dedere aut punire formulada por Grocio no es una solución aleatoria que se obtiene dos mil años después sino uno de los muchos préstamos tomados del ius publicum del AOM por al ius publicum europeum a través del $A T$, sin tener conciencia de ello. También se dispone de pruebas de que la experiencia normativa internacional del II Milenio $a$. $C$. influyó en el mundo greco-romano antiguo. Esta sería la otra gran fuente de inspiración de derecho internacional del s. XVI d. C. en adelante.

Incluso cuando no existía un tratado bilateral, el hecho de no entregar personas o poblaciones desplazadas de un territorio a otro era un acto considerado como hostil que se oponía a la voluntad de otro soberano de ejercer su jurisdicción ratione personae sobre el huído. Se muestra así que se trata de una problemática universal en el tiempo a la que conduce invariablemente la existencia de formas territoriales extensas de ejercicio de los poderes políticos. Hace emerger dos modos potencialmente en disputa para el ejercicio válido de la jurisdicción; dos conexiones objetivas entre un poder público y los individuos, la personal y la espacial, hábiles para justificar normativamente un título jurisdiccional. La existencia de un deber internacional general de extradición era una cuestión dudosa.

Más en general, los textos demuestran que el derecho internacional público emerge como unsistema de normas escritas que regulan de modo amplio las relaciones políticas básicas entre los Estados territoriales desde el II milenio a. C. en el área 
regional del AOM. El reconocimiento de gobiernos y las cuestiones sucesorias, la delimitación territorial y su integridad, el alcance de los poderes soberanos o las reglas sobre flujos migratorios son abordados sistemáticamente en tratados. Éstos forman parte del largo caudal del derecho desde los orígenes de la civilización. La sistematización escrita de los derechos internos y del derecho internacional aparece simultáneamente en el mismo espacio y tiempo.

\section{BiBLIOGRAFÍA}

Alp, Sedat, Hethitische Briefe aus Maşat-Höyük (Ankara, Turk Tarih Kurumu Basemevi, 1991).

Altman, Amnon, Rethinking the Hittite System of Subordinate Countries from the Legal Point of View, en Journal of the American Oriental Society, 123/4 (2003), pp. 741-756.

Beal, Richard H., Making, Preserving and Breaking Peace with the Hittite State, en Raaflaub, Kurt A. (ed.), War and Peace in the Ancient World (Oxford, John Wiley \& Sons, 2007), pp 81-97.

Beckman, Gary M., Hittite diplomatic texts (Atlanta, Scholars Press, 1996).

-International Law in the Second Millenium: Late Bronze Age, en Westbrook, Raymond (ed.), A History of Ancient Near Eastern Law (Leiden - Boston, Brill, 2003), I, pp. 753-776.

Bell, Lanny, Conflict and Reconciliation in the Ancient Middle East: The Clash of Egyptian and Hittite Chariots in Syria, and the World's First Peace Treaty among 'Superpowers', en Raaflaub, Kurt A. (ed.), War and Peace in the Ancient World (Oxford, John Wiley \& Sons, 2007), pp. 98-122.

Bernabé, Alberto, Textos literarios hetitas ( 1979, Madrid, Alianza Tres, 1987).

Bernabé, Alberto; Álvarez-Pedrosa, Juan Antonio, (eds.), Historia y leyes de los hititas. Textos del Imperio Antiguo. El Código (Madrid, Akal, 2000), 2 vols.

Bryce, Trevor, Hitite State and Society, en Genz, Herman; Mielke, Dirk Paul (eds.), Insigths into Hittite History and Archaeology (Leuven-Paris-Walpole MA, Peeters, 2011), pp. 85-98.

—Life and Society in the Hittite World (Oxford, Oxford University Press, 2002).

- The Kingdom of the Hittites (Oxford, Oxford University Press, 2005).

Chirichigno, Gregory C., Debt Slavery in Israel and the Ancient Near East (Shefield, A\&C Black, 1993).

Coluns, Billie Jean, The Hittites and their World (Atlanta, Society of Biblical Literature, 2007).

Galvin, Garrett, Egypt as a Place for Refuge (Tubingen, Mohr Siebeck, 2011).

García Trabazo, José Virgilio, Textos religiosos hititas: Mitos, plegarias y rituales (Madrid, Trotta, 2002).

GonZÁlez SAlaZAR, Juan Manuel, Victimas olvidadas. Observaciones sobre el comportamiento de los hititas con sus prisioneros en la frontera centro-septentrional de su Imperio, en Gerión, 31 (Madrid, 2013), pp. 15-50.

Grotil, Hugonis, De Iure Belli ac Pacis Libri Tres (Carnegie, Institute of Washington, 1913), 3 vols.

Hagenbuchner, Albertine, Die Korrespondenz der Hethiter Albertine (Heidelberg, C. Winter, 1989), 2 vols. 
Hoffner (JR.), Harry A., Letters form the Hittite Kingdom (Atlanta, Society of Biblical Literature, 2009).

Killebrew, Ann E., Hybridity, Hapiru, and the Archaeology of Ethnicity in Second Millennium BCE Western Asia, en McInerney, Jeremy (ed.), A Companion to Ethnicity in the Ancient Mediterranean (Chichester - West Sussex, Wiley Blackwell, 2014), pp. 142-157.

KIngsLey, Davis, The World Demographic Transition, en Annals of the American Academy of Political and Social Science, 237 (Philadelphia, 1945), pp. 1-11.

Klengel, Horst, History of the Hittites, en Genz Herman; MielKe, Dirk Paul (eds.), Insigths into Hittite History and Archaeology (Leuven-Paris-Walpole MA, Peeters, 2011), pp. 31-46.

Laroche, Emmanuel, Catalogue des textes hittites (Paris, Klincksieck, 1971).

Liverani, Mario, La lettere di el-Amarna (Paideia, Brescia, 1998-1999), 2 vols.

Lorenz, Jürgen; SchraKamp, Ingo, “Our Master! Do not destroy us!” The Fate and Role of Non-Combatants in the Wars of the Hittites, en Nadal, Davide; VIDal, Joan (eds.), The Other Face of the Battle. The Impact of War on Civilians in the Ancient Near East (Münster, Ugarit-Verlag, 2014), pp. 37-64.

Mendelsohn, Isaac, Slavery in the Ancient Near East (1898, Oxford, Greenwood Press, reimpr. 1978).

Moran, William. L., The Amarna Letters (Baltimore - Londres, Johns Hopkins University Press, 1992).

Mynarova, Jana, Language of Amarna - Language of Diplomacy: Perspectives on the Amarna Letters (Praga, Czech Institute of Egyptology, 2007).

Singer, Itamar, Hittite Prayers (Atlanta, Societal of Biblical Literature, 2002).

-The Urhi-Tessub affair in the Hittite-Egyptian Correspondence, en VAN DEN HouT, Theo P. J. (ed.), The Life and Times de Hattusili III and Tuthaliya IV. Proceedings of a Symposium held in Honour of J. De Roos, 12-13 December 2003 (Leiden, Nederlands Instituut voor het Nabije Oosten, 2006), pp. 27-38.

SNell, Daniel C., Flight and Freedom in the Ancient Near East (Leiden - Boston, Brill, 2001).

Weeden, Mark, State Correspondence in the Hittite World, en Radner, Karen (ed.), State Correspondence in the Ancient World. From New Kingdom Egypt to the Roman Empire (Oxford - New York, Oxford University Press, 2014).

Westbrook, Raymond, Personal Exile in the Ancient Near East, en Journal of the American Oriental Society, 128/2 (2008), pp. 317-323. 